\title{
Traditional Confucianism and its Contemporary Relevance*
}

\section{LE CONFUCIANISME TRADITIONNEL ET SA PERTINENCE CONTEMPORAINE}

\begin{abstract}
LIN Hang ${ }^{1}{ }^{\dagger}$
Abstract: After a century of its retreat from political and social stages in East Asia, Confucianism eventually found its revival together with the economic industrialization in the region. The awakening consciousness of the traditional Confucian values leads to a reconsideration of their implication on a modern society. Despite the criticism on the actual relevance of Confucianism and modernization, there are precious elements within the Confucian values which provide the relevance of Confucianism to the future, such as an ethic of responsibility and the understanding of the humanistic meaning of life.

Key words: Confucianism; East Asia; Traditional Values

Resumé: Après un siècle de sa retraite des scènes politique et sociale en Asie de l'Est, le confucianisme a finalement trouvé son renouveau avec l'industrialisation économique dans la région. L'éveil de la conscience des valeurs confucéennes traditionnelles conduit à un réexamen de leur implication sur une société moderne. Malgré la critique sur la pertinence réelle du confucianisme et de la modernisation, il y a des éléments précieux dans les valeurs confucéennes qui fournissent la pertinence du confucianisme à l'avenir, comme une éthique de responsabilité et de la compréhension de la signification humaniste de la vie.
\end{abstract}

Mots-clés: Confucianisme; Asie De L'est; Valeurs Traditionnelles

DOI: $10.3968 / j . c c c .1923670020110702 .004$

\section{INTRODUCTION}

Ever since the birth of Confucianism around 2.500 years ago, generations of Confucians have long been preoccupied with social and political change. Both Confucius [c. 551-479 BC] and Mencius [c.390-305 BC] moved from state to state, looking for opportunities to put their political ideals into practice, but became disenchanted with political life and settled for a teaching career. Several hundred years later, nevertheless, the social and political ideas of Confucius and Mencius, as documented in the Analects of Confucius and the Works of Mencius, proved to be literally world transforming. After the harsh practice of Legalism in the short-lived Qin dynasty [221-206BC], the following Han dynasty [202BC-220AD] abandoned the Taoism and finally adopted Confucianism as its official ideology (Yao, 2000, p.81-82). For the next two thousand years, the country's scholars and literati sought to make it more relevant in particular situations with novel features. By the end of the thirteenth century, the whole east Asian region was thoroughly, or at least considerably, "confucianized" (Duncan, 2002, p.65-67).

\footnotetext{
* This publication was funded by the German Research Foundation (DFG) and the University of Würzburg in the funding programme Open Access Publishing.

${ }^{1}$ Institute for Cultural Studies East- and South Asia - Sinology, University of Würzburg, Germany; Graduate School of the Humanities, University of Würzburg, Germany.

$†$ Corresponding Author. Email: hang.lin@uni-wuerzburg.de

$\$$ Received May 30, 2011; accepted June 15, 2011.
} 
Modern Confucianism has engaged in a long process of survival and renovation since as long as the end of the seventeenth century. However, since the advent of modernity in the second half of the nineteenth century, Confucians has fared less well. The arrival of western culture essentially rejected the self-change and self-adjustment preferred by the Confucians, while the collapse of Confucian states in East Asia meant that old Confucianism was no longer vital enough to merge the societies in the new context, and to survive, Confucian scholars were pressed into a painful procedure of searching the answers to the question of why it had lost its political, social, cultural and idealogical influence, and whether it could maintain its moral and spiritual bases (Yao, 2000, p.264-265). Eventually, this search elaborated itself to the tackling of the following questions: Will Confucianism have much to offer and to contribute to a meaningful life in a rapidly changing society?Are Confucian values to be promoted in contemporary societies? Or to be more exactly, how can Confucianism shake off its negative elements while enhancing its positive relevance for the future?

\section{THE REVIVAL OF CONFUCIAN VALUES}

Since the Confucian retreat from social, political and economic stages in East Asia by the the end of the nineteenth century, the Confucian influence has been considerably limited to a small area, seemingly viable only among the traditionally minded people and merely a subject of philosophical or religious researchers. Max Weber, one of the earliest scholars in the West to devote serious attention to the relationship between Confucianism and modernity, singled out "Confucianism" among major "world religions" as the least conductive to capitalist economic development (Weber, 1963, p.269). East Asian countries, for their part, began to condemn this venerable tradition as they deepened their encounter with the West since then. Indeed, for the vast majority of East Asians, modernity had come to mean overcoming Confucianism.

This is, of course, only one side of the story. The umbilical cord between the Confucian tradition and modern China, as well as modern East Asia, can not be easily served. Various elements of Confucian heritage, in whatever form it may take, have been transmitted to the present, either hidden in Nationalist or Communist doctrines, principles, or implicitly in underlying the whole structure of the Chinese society (Levenson, 1958, p.126-128, 135). The link between Sun Yat-sen's Three Principles of the People (sanmin zhuyi 三民主義), for instance, and the Confucian version of the Grand Unity Society (datong shehui 大同社會) is so strong that very few people would deny that the former is to some extent a succession of the latter. The Communists, on the other hand, were also highly inspired by the Confucian moral code, that David Nivison even argued that the Chinese Communist ethics at its beginning and Confucianism were not very different in practice, though in different appearance (Nivison, 1972, p.207-230). Hence, this invisible heritage has set the seed of the revival of Confucianism even after many years of disruption of its tradition.

While the advanced industrialized countries were mired in the vicious cycle of stagnation, and while the Arabic struggled to resist the industrialization and democratization, the countries in East Asian continued to flourish through the 1960s and 1970s, as the cased of Singapore, Korea, and Taiwan demonstrated, and then since the 1980s as China does. Since the 1980s, the awakening consciousness of Confucianism in the recent time is aslo related to the renewal of culture and the transformation of traditions. During the search of a new form and new interpretation of the Confucianism, two aspects are stressed to act as "Confucianism as the source of moral values" and as "Confucianism as the structure of a society" (Samrt, 1989, p.104), or as "idealistic and cultural Confucianism" and as "dynastic and social Confucianism" (Li, 1994, p.340-345; Li, 1999, p.129). Hence, while the social and political structure of traditional Confucianism has long been demolished, its idealist values and ethics remain inherent in Chinese psychology and underline East Asian people's attitudes and behavior (Tu, 1996, p.259).

As Confucianism has been on the rise again in many East Asian countries, although the reasons and motives behind its developing popularity are quite different from one country to another. This then inevitably led to much discussion regarding the role Confucianism in the modernization of East Asia, particularly in the economics and politics. Those who initially argued that Confucianism held the secret to the region's economic success were most Western scholars, among others such as Roderick MacFarquhar, Kent Calder and Roy Hofheinz Jr., and Ezra Vogel. The first among the East Asians to openly and enthusiatically espouse the idea of that Confucianism stood behind the economic development were politicians. Singapore's statesman Lee Kuan Yew has invoked Confucian values, in the guise of "Asian values", to justify constraints on the democratic process (Chua, 1997, p.154). Other authoritarian governments in the region have similarly appealed to Confucian values to lay their stress that the political and economic system they erected was in many ways superior to that of the West.

Despite the criticism on the relevance of Confucianism and modernization, Confucianism is however gradually regaining some of the space it traditionally held in the people's mind. The old tradition may not have obtained any new identity, nor may the old political systems and social structures be appreciated again, but Confucian values are no longer disliked, as a hundred years ago, and some of them even become appealing. The combination of Confucian values and modern qualities creates a new title for business leaders in China, the "Confucian entrepreneurs" (rushang 儒商), for their 
demonstration of Confucian values auch as humaneness, sincerity and truthfulness (Chen, 2007). Along with the new understanding of the nature and function of Confucianism, efforts have also been made to rejuvenate and rehabilitate Confucian institutions, and interests in the Confucian education system are on the increase. For example, after the interval of almost a century, the traditional civil service examination, which bears the dominent mark of Confucian teachings, has partly been adopted as a modern means to recruit cilvil servants in China (Zheng, 207, p.314). In 2005, the renominate Renmin university in Beijing even established the first in its type a "College for National Studies" , which is more exactly a rendering for a college for Confucian classics.

\section{CONFUCIAN ELEMENTS FOR MODERN SOCIETY}

These may not be enough to claim the glorious status of Confucianism in the past. Nonetheless, nobody would doubt that the old tradition has become gradually relevant again to modern social, personal, and to some extent, religious life in China. If it is true that an understanding of the Chinese and East Asian cultures and societies in the history was impossible without an appreciation of Confucianism, then it has now become true that a picture of China and East Asia today which takes no account of Confucianism is obviously partial or superficial. Of course, the revival of Confucianism is by no means to be viewed as the existence of an isolated tradition behind the process of East Asian modernization. It is in the new context not a wholesale revival of the tradition, but as a transformed doctrine which can provide useful elements for a modern society. In this sense, new confucian values are actually "post-Confucian" values, as moderated somehow to modern values (Taylor, 1988, p.212).

To answer the question what exact elements makes Confucianism relevant to modern society, some single out Confucian understanding of family as the reason for its modern relevance. Indeed, this holds legitimacy that family in Confucian context, or Confucian clanism, is culturally and psychologically relatively important for an East Asian society. Family values are admittedly significant for the stability and continuity of a modern society, and "in the post-Confucian societies, family continues to serve as a vital institution for social cohesiveness, moral education, spiritual growth, and capital formation" (Tu, 1991, p.38). Nevertheless, there are also arguments opposing the identification of the modern values of Confucianism with traditional clanism, which trace back to the Confucian classics:

The Master said: “... The father conceals the misconduct of the son, and the son conceals the misconduct of the father. Upright is is to be found in this." (Analects of Confucius, XIII: 18.)

“... Between father and son, there should be affection; ... between husband and wife, attention to their separate functions; between old and young, a proper order; and between friends, fidelity. ...” (Works of Mencius, IIIa: 4)

As shown in the words of Confucius and Mencius, there are several argued reasons why the Confucian clanism can not play as the key element for Confucian relevance to the twenty-first century. Firstly, the traditional family relations, defined by the Confucian moral and legal codes, is not abundant enough to meet the requirements of the characteristics of a modern society, namely flexibility, mobility, equality, as well as democracy. Secondly, the traditional clanism has brought too many negative by-products. For instance, the Confucian clanism contributes to a social fabric in which personal connections rather than codes of public conduct are of more importance. This can lead to the precedence of hierarchy, patriarchal attitudes, and favoritism, which hinders the implementation of market economy and the building of a civil society (Krieger \& Trauzettel, 1991, 350-357).

Due to the different context and settings of transformed social, cultural, and political background, what makes Confucianism a living tradition can not be any fixed pattern of family or hierarchical politic stratification, which would not be proper to be implemented in a modern society, but rather its moral and spiritual values. Among those values, probably the most precious elements which provide the relevance of Confucianism to the future can be the concern about moral responsibilities of an individual and the humanistic recognizing of human life, because they will make a significant contribution to an ethic of responsibility and give a new momentum to the understanding of the humanistic meaning of life.

\section{AN ETHIC OF RESPONSIBILITY}

It has been common sense that free choice, together with a established law system with its protection of individual rights are the foundation of modern society and the precondition of a market economy. However, a absolute freedom without responsibility would results to both struggle among individuals and chaos in the social network, and would therefore lead to satisfy the short-tern needs at the cost of the long-term future. In this respect, Confucianism can probably make its 
contribution to the resolution of this question through a new moral sense, a new ecological view, as well as a new understanding for the globe village (Taylor, 1986, p.23; Hahm, 2003, p.43-44).

The Master said: "The superior man, in the world, does not set his mind either for anything, or against anything; what is righteous he will follow." (Analects of Confucius, IV: 10)

The philosopher Zeng said: "I daily examine myself on three points: - whether, in transacting business for others, I may have been not faithful; - whether, in intercourse with friends, I may have been not sincere; whether I may have not mastered and practiced the instructions of my teacher." (Analects of Confucius, I: 4)

It is true that Confucianism insists that the self to be the center of all personal and social relationships, however, it does not aims at the claim of one's rights but at the emphasis on one's responsibility. It advocates that one's daily behavior ought to be guided by the rules of rites or propriety, not merely for restricting individuals, but more for the cultivation of the sense of holiness, not primarily for conquering, but more for co-operating with others to contribute to the harmony of the universe.

The Confucian effort in building an ethic of responsibility coincides with the growing global conscience, and can been seen as a part of the international search for a universal co-operative ethic to guide the world community. Since the 1990s, a series of events and projects has already been aiming at dealing with the moral problems of the world and trying to establish an universal civic ethic. For example, the Commission ob Global Governance, led by former German Chancellor, Willy Brandt, published a report entitled "Our Global Neighborhood" in 1995, promoting the conception of "global ethics" for "global" citizens (Ankerl, 2000, p.371). Although this report interpreted the term "our" as the expectation that the value order of European humanistic tradition is to be automatically shared by the whole world, it at least unfolded a diskussion on the possibility and necessity of a declaration on universal ethics. It is against this background, UNESCO established the Universal Ethics Project in 1997 to provide a platform for politicians, philosophers, and ethicists to test the viability and coherence of their ideas. And this time, two from the camp of modern Confucianism were involved, Wei-ming Tu of Harvard, and Shuxian Liu of Kong Hong (Kim, 2000, p.88). In a sense, whether such a proposal for a universal ethic can be successfully determined or put in place is not of primary importance. The real great significance of these events lies actually more in the attention to the possibility of a shift from a rights-based morality to a responsibility-emphasized ethic. In this process then, Confucianism certainly has its instrumental role to play.

\section{THE HUMANISTIC MEANING OF LIFE}

The Mater said: "I do not know how a man without truthfulness is to get on. How can a large carriage be made to go without the cross-bar for yoking the oxen to go, or a small carriage without the arrangement for yoking the horses?" (Analects of Confucius, II: 22)

The Master said: “... From the ancient, the death has been always unavoidable, but if people have no truthfulness, then they will have nothing to stand on." (Analects of Confucius, XII: 7)

The words of Confucius illustrate that ever since the founding of Confucianism, this tradition has always cherished the truthfulness and faith, the meaning of which are virtually to be understood in two dimensions. In the first, it refers to the personal faith and trust, which enables people to endure the sufferings and to construct reliable relations between individuals. Secondly, it also refers to the mutual commitment between people and the whole society or the government, without which the social order is hardly to be maintained.

Without any doubt, trust and truthfulness is fundamental to any society, however, various traditions and cultures have various dimensions or expressions of the term. The current religious world is considerably dominated by the "theo-centric" faiths, such as Christianity, Islam, Hinduism, Buddhism, or even Shamanism, which all more or less devote their understanding to their own religions. In a different way to express its concern about human life, Confucianism represents an essentially "anthropo-centic" approach towards faith and trust, characterized by its belief in the ability of humans themselves to cultivate themselves and to transform the world and their lives (Yao, 2000, p.284). For the reason that Confucianism carries such an obvious appearance as a secular doctrine and is therefore often be described as a purely pragmatic system promoting human material welfare only, the key question about the spiritual values of Confucianism may be: Is Confucianism able to provide a faith by which its followers can find eternal meaning in temporal life? The failure to explore the spiritual dimension of Confucianism easily leads to the perception that Confucianism lacks metaphysical depth. The misunderstanding of Confucian values by modern interpreters, in particular those under heavy influence of pragmatism arose in the May Fourth Movement, is due to "an ignorance of this metaphysical dimension of Confucian concern (de Bary and Chaffee, 1989, p. 139). However, it is argued that since faith is essential for a society and 
since Confucianism does not hold such a faith, Confucianism is therefore unable to make any contribution to spiritual life and an alternative must be found in the sources outside Confucianism itself (Weber, 1968, p.243).

The weakness in the former mentioned reasoning is, however, that it only allows one single type of faith, while denying the existence of different kinds of faith. The alternative Confucianism provides is that the Confucian faith "fundamentally humanistic", which lays the responsibility for a better world in the hands of the human being itself rather than in the hands of a supremely detached God (Yao, 1996, p.15-16). In this sense, Confucianism represents a different approach toward the meaning of life.

The Master said: "A gentleman in the world, is free from unreasonable likes and dislikes. He stands for what is righteous." (Analects of Confucius, IV: 10)

The Master said: "The determined scholar and the man of virtue will never seek to live at the expense of injuring their virtue. They will be ready to sacrifice their lives to preserve the virtue." (Analects of Confucius, $\mathrm{XV}: 8)$

These words demonstrated the ultimate mission of a person in the world. For a Confucian, the meaning of life can be realized not through a religious creature or mental belief, but through moral self-cultivation and self-transformation, the commitment of oneself to the welfare of the family, community and society, as well as the influence of his moral and cultural realms over the world. This search for a spiritual meaning in public life is not only crucial for Confucian spirituality, but also for the adaption of the humanistic belief to meet the spiritual demands of a multicultural society, as this search may only be completed by isolating itself from other religious and non-religious traditions.

\section{CONCLUSION}

The modern era of Confucianism began with its response to the challenges of Western powers and was labelled as the origin of the blame for intellectual, political and social failures of East Asia in the modern time. The process if rapid industrialization of East Asian countries since the 1970s brought about cultural confidence and the need for traditional values again. Since then, academics and politicians have come to rethink their cultural tradition more positively and to reclaim its relevance for the modern world. In the enthusiastic search for the cultural root, Confucianism is brought into focus, and become again relavant to people's lives.

Upon the question "why Confucius now", William Theodore de Bary stresses that Confucianism is not only relevant in East Asian societies, but also for the whole world (de Bary, 2003, p.367). He suggests a multicultural education for a world community, where Confucianism should be give a solid place within the curricula. The question of what values can sustain a modern world is not of course a purely East Asian or Chinese one. However, some values find its sense in the contemporary world by directing the attention of people on the moral and spiritual values rather than focusing only material welfare, such as the emphasis of Confucian traditions on realizing the ethic of responsibility and understanding the humanistic meaning of life. The rethinking and reinvestigating of Confucianism does not mean a simple revival of old values, but rather a reconsideration and reevaluation of the essence of its ideas. Nevertheless, coming to terms with one's own past culture, especially for the East Asians, will be an essential element in arriving the self-understanding that is the precondition for understanding others.

\section{REFERENCES}

Ankerl, G. (2000). Global Communication with Universal Civilization, 1. Chicago: Illinois University Press.

Chen, Shulu. 陳書錄 (2007). Rushang ji wenhua yu wenxue 儒商及文化與文學 (Confucian Entrepreneurs, Culture, and Literature). Beijing: Zhonghua Shuju.

Chua, B. (1997). Communitarian ideology and democracy in Singapore. New York: Routledge.

de Bary, William Theodore (2003). Why Confucius Now. In D. A. Bell \& C. Hahm (Eds.), Confucianism for the Modern

World (pp. 361-372). Cambridge: Cambridge University Press.

Duncan, J. B. (2002). Examinations and Orthodoxy in Chosŏn Dynasty Korea. In B. A. Elan, J. B. Duncan \& H. Ooms

(Eds.), Rethinking Confucianism: Past and Present in China, Japan, Korea, and Vietnam (pp. 65-94). Los Angelas:

University of California.

Hahm, C (2003). Constitutionalism, Confucian Civil Virtue, and Ritual Propriety. In D. A. Bell \& C. Hahm (Eds.),

Confucianism for the Modern World (pp. 31-53). Cambridge: Cambridge University Press. 
Kim, Y. (2000). Philosophy and the Prospects for a Universal Ethics. In M. L. Stackhouse \& P. J. Paris (Eds.), God and Globalization: Religion and the Powers of the Common Life (vol. 1) (pp. 69-104). London: Continuum International Publishing Group.

Legge, J. (1970). The Chinese Classics, $1 \& 2$. Taipei: Dunhuang shuju.

Levenson, J. R. (1958). Confucian China and Its Modern Fate (Volume One): The Problem of Intellectual Continuity.

London: Routledge and Kegan Paul.

Li, Yi 李毅 (1994). Zhongguo Makesi zhuyi yu xiandai xin Rujia 中國馬克思主義與現代新儒家 (Chinese Marxism and Modern New Confucianism). Shengyang: Liaoning University Press.

Li, Zehou (1999). Human Nature and Human Future: A Combination of Marx and Confucius. In K. Pohl (Ed.), Chinese

Thought an a Global Context: A Dialogue Between Chinese and Western Philosophical Approaches (pp. 129-144).

Leiden: E.L. Brill.

Nivison, D. S. (1972). Communist Ethics and Chinese Tradition. In J. Harrison (Ed.), China: Enduring Scholarship

Selected from the Far Eastern Quarterly - The Journal of Asian Studies 1941-1971 (Vol. 1) (pp. 207-230). Arizona:

The University of Arizona Press.

Samrt, N. (1989). The World's Religions. Cambridge: Cambridge University Press.

Taylor, R. L. (1986). The Way of Heaven: An Introduction to the Confucian Religious Life. Leiden: E.J. Brill.

(1988). The Confucian Way of Contemplation: Okada Takehiko and the Tradition of Quiet Sitting. Columbia: University of South Carolina Press.

Tu, W. (1989). The Sung Confucian Ideas of Education: A Background Understanding. In W. T. de Bary \& J. W. Chaffee

(Eds.), Neo-Confucian Education: The Formative Stages (pp. 139-150). Berkeley, Los Angelas and London:

University of California Press.

(1991). A Confucian Perspective on the Rise of Industrial East Asia. In S. Krieger \& R. Trauzettel (Eds.), Confucianism and the Modernization of China (pp. 29-41). Mainz: v. Hase \& Koehler Verlag.

(Ed.). (1996). Confucian Traditions in East Asian Modernity: Moral Education and Economic Culture in Japan and the Four Mini-Dragons. Cambridge: Harvard University Press.

Weber, M. (1963). The Sociology of Religion. Boston: Beacon Press.

(1968). The Religion of China: Confucianism and Taoism. New York: Free Press.

Yao, X. (1997). Confucianism and Christianity: A Comparative Study of Jen and Agape. Brighton: Sussex Academic

Press.

(2000). An Introdution to Confucianism. Cambridge: Cambridge University Press.

Zheng, Ruoling 鄭若玲 (2007). Keju, Gaokao yu shehui zhi guanxi yanjiu 科舉, 高考與社會之關係研究 (A Study onf the Relation Between the Imperial Civil Service Examination, University Entrance Examination, and the Society). Wuhan: Central China Normal University Press. 